\title{
歩道景観における全体評価と構成要素の評価・注目度・面積率との関係 に関する研究

\author{
RELATIONSHIP BETWEEN TOTAL EVALUATION OF TOWNSCAPE, \\ ELEMENT'S EVALUATION, ELEMENT'S ATTENTION LEVEL \\ AND ELEMENT'S AREA RATE ON SIDEWALKS
}

\author{
山口満* \\ Mitsuru YAMAGUCHI
}

\begin{abstract}
Relationship between total evaluation of townscape, element's evaluation, element's attention level and element's area rate are analyzed by studying 1.whole sidewalk view evaluation, 2.composed elements evaluation, 3.composed elements attention level, 4.composed elements area rate from a photograph.

As a result, the relationship between total evaluation of townscape and composed elements from evaluation, attention level, area rate, can be defined by using their correlation. And composed elements are classified by using total evaluation and correlation, evaluation, attention level, area rate and correlation. Besides, realizations of classified composed elements are considered.
\end{abstract}

Keywords : sidewalk, townscape, evaluation, attention level, area rate, element 歩道, 景観。評価, 注目度, 面積率, 構成要素

\section{1. はじめに}

人間が景観を評価する場合，評価対象としてまとまりのある何ら かの対象を認識しなければならない。しかし，そもそも景観とは， 人間が認識することによって何らかのまとまりを与えるものであ るとも考えられる。従って, 景観の評価は評価対象の認識のされ方 とともに考察する必要がある。

本研究は, 景観認識のされ方を歩道から見た景観における「全体 評価」と「構成要素の評価・注目度・面積率」との関係から捉えよ うとするものであり，次の 4 つの内容相互の関係を探ることが本研 究の目的である。

(1) 歩道景観全体の評価

(2) 各歩道景観構成要素の評価

(3) 各歩道景観構成要素の注目度

(4) 各歩道景観構成要素の写真に占め万面積率

\section{2. 既往研究からの位置づけ}

筆者らも含めて,これまでに景観を対象として様々な評価分析が なされてきている。

初期の研究としては, 奥の研究注 1) と船越らの研究注 2) がある。奥 の研究は視覚特性に基づいて街路景観構成要素の心理的効果を明 らかにしたものであり, 船越らの研究は街路空間構成要素の物理量 と心理量との関係を明らかにしたものである。
街路景観における全体景観と構成要素との関連性について考察 している研究もいくつかある。松本らの研究注 ${ }^{3)}$ は, 視覚的特徵で ある乱雑・整然性に着目し，それらを生じさせる構成要素について 考察しているものであるが，景観評価の「好ましさ」は直接扱われ ていない。槙らの研究注 4) は, 景観を評価する場合に考慮される項 目と評価との関連性を調べ，評価項目が景観ごとに異なることを明 らかにしたものであるが, 物理的要素がどの様に影響しているかは 考察されていない。

最近の研究としては，高木らの研究注 5)，辻川らの研究注 6) がある。 高木らの研究は, 人間の環境に対する深い心理作用の存在を見つめ, そこからく詩性〉という概念を導きだしたものである。本研究で明 らかにしようとする評価対象の認識のされ方とく詩性＞という概 念との関係が興味深い。辻川らの研究は, 都市空間構成要素として のストリート・ファニチュアを，人との関わり方で分類し，歴史的 な変遷を明らかにしたものであるが，人間の認識にまで考察は及ん でいない。

筆者らもこれまでに駅間空間を対象に景観の研究を行ってきて おり, 本研究は, 筆者らの既往研究注 7)の続編である。既往研究で は, 駅前広場の代表的な物理的要素の “好ましさ”と，駅前広場全 体景観の “好ましさ”“多様性” “楽しさ”“整然性”との関係から， 物理的要素とそれらによって構成された全体景観との評価におけ る関係性を考察したものであり，全体景観と各構成要素との関倸を

\footnotetext{
* 信州大学工学部社会開発工学科建築コース 講師・博士 (工学)

Lecturẹr, Dept. of Architecture, Faculty of Eng., Shinshu Univ., Dr. Eng.
} 

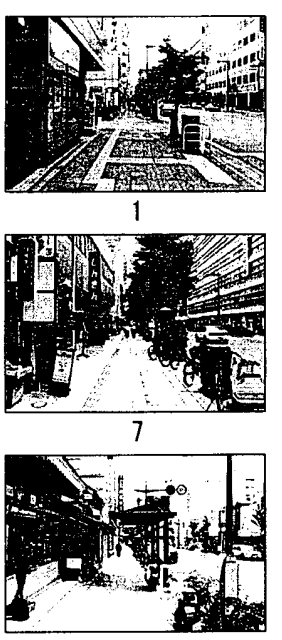

13
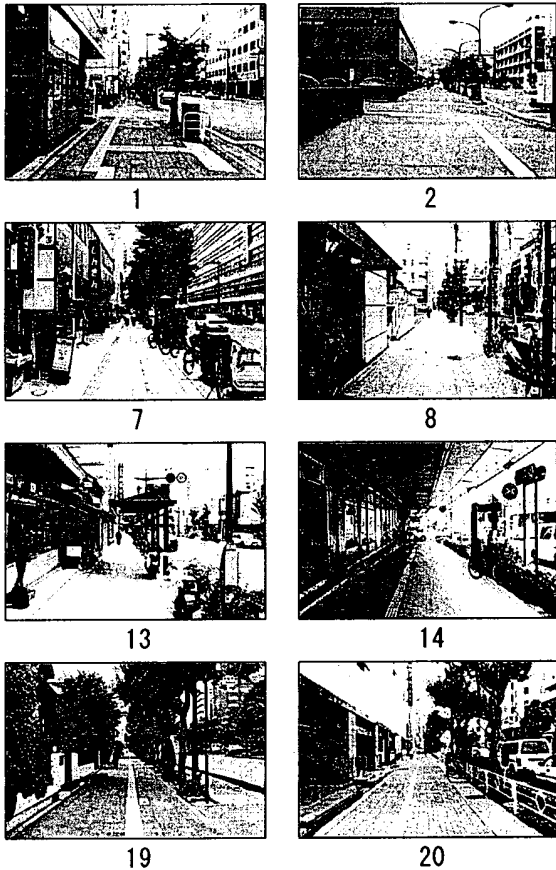

2

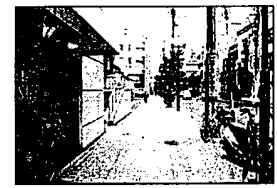

8

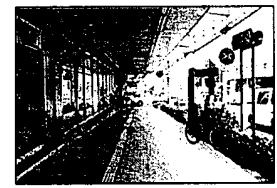

14

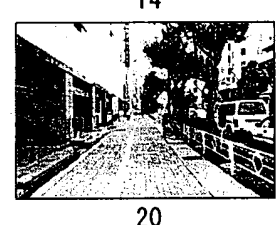

20

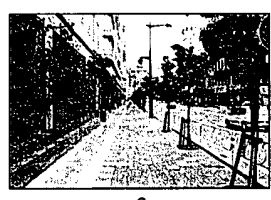

3
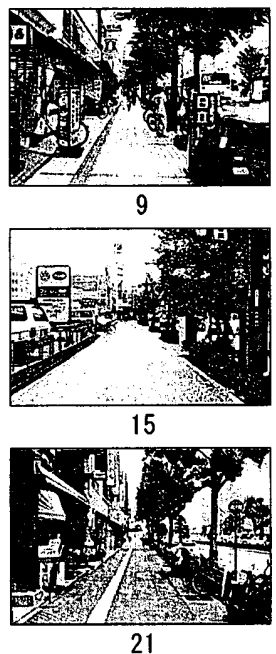

21

写真 1 分析・考察に用いた写真

明らかにしている。本研究は, 全体景観と構成要素の評価における 関倸性だけではなく, 構成要素の注目度や面積率といった観点を加 えて景観評価の内容を考察している。

\section{3. 歩道景観評価実験の概要}

人間は，目に写ったもの注 8)，すなわち網膜を刺激しているもの をそのまま認識しているのではなく, 網膜の刺激の中から人間の思 考を通してある存在を浮かびあがらせつつ認識していると考えら れる。つまり，常に物理的刺激に対して人間の意識を織り重ねつつ 認識していることになり，景観評価も，意識によってまとめられた 何らかの存在を評価対象の景観として認識することが前提となっ ていると考えられる。

そこで，意識がどのように物理的刺激をまとめあげているかを探 るため，歩道景観を対象として以下の(1)〜(4)をそれぞれ調査する実 験注 9)を行った。

(1) 歩道景観全体の評価

(2) 各歩道景観構成要素の評価

(3) 各歩道景観構成要素の注目度

(4) 各歩道景観構成要素の写真に占める面積率

対象は歩道から見た景観を撮影したカラー写真とし，まず，歩道 景観全体の評価とその景観を構成している歩道景観構成要素の評 価とを, “好ましい一好ましくない”という形容詞尺度を用いた 7 段階評定の評価実験によって，それぞれ個別に測りとっている。つ ぎに, 歩道景観全体の評価を行った際に注目した構成要素について 記述してもらい，記述された頻度をその構成要素の注目度として測 りとっている。さらに, 使用したカラ一写真における各歩道景観構 成要素が占める面積率を計測している。なお, 歩道景観構成要素の 注目度および面積率を考察対象とするため, 評価対象としてカラー 写真を用いている。
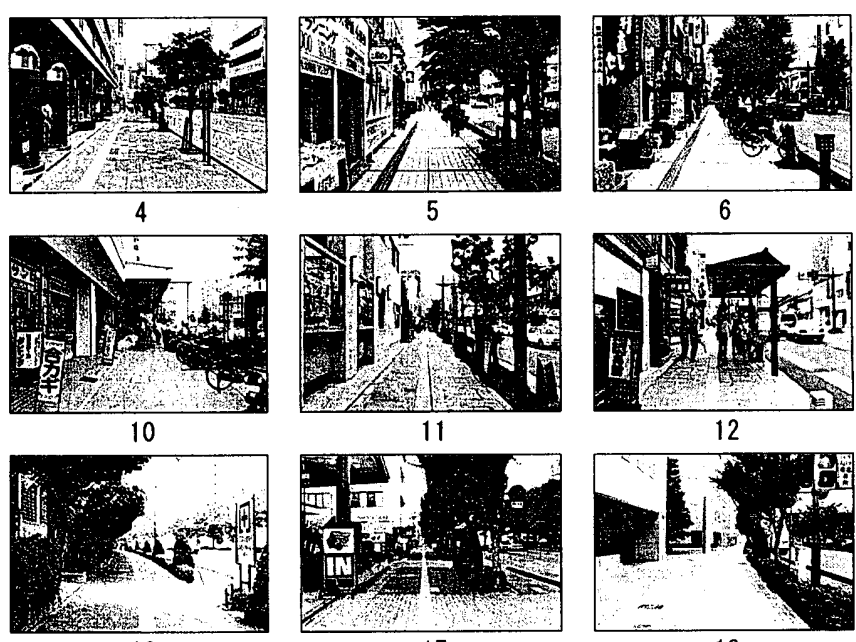

17

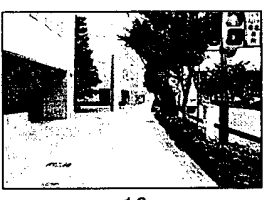

18

\section{表 1 写真撮影基準}

(1) 使用レンズ: $35 \mathrm{~mm}$

(2) 步道延長方向の撮影地点乩び撮影方向:街の察囲気が变化する地点(ある 用気の端点〉からとするため，交差点を渡り終えた地点から先に向かう方向，あるい は街の察囲気が変化する地点から繁囲気が繶く方向とした。

(3) 步道幅員方向の撮影地点: 進行方向に対して車道左側の歩道において, 放置自 転車・建物のセットバックなどが特殊な状況になっている場合は通行できる幅員の 中央 その他の場合は歩道幅員の中央とした。

(4) カメラの高さとレンズの仰角: 目の高さ(約 $160 \mathrm{~cm}$ )から, 俯角 $8^{\circ} \sim 10^{\circ}$ で撮影した。

(5) 撮影日:長野駅周辺の 21 林は 1996 年 7 月 $15 \cdot 30$ 日の両日に, 住宅街の 8 枚は 7 月 22 日に撮影した。

(6) 撮影時間: 13:00〜16:00 とした。

(7) 天侯: 罢天(薄䅪りも含む)とした。

(8)その他:普段の人混みや交通量と大差ないこと, 人が横切ったりするなど人が画面 を大幅に占めることがないこと、に留意した。

器問 1 街路を見て。街路全体の印象に関して「好ましいー好ましくない

という詳価を, 以下の7段陼で行ってください。

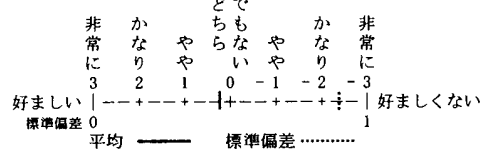

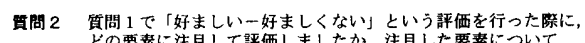

下の写真に○を付けるか，下のカッコ內に要素の名称を記入してください。
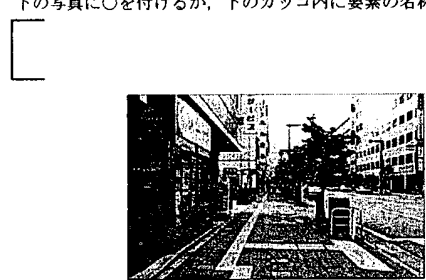

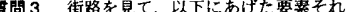

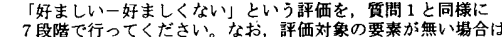
段階で行ったください。

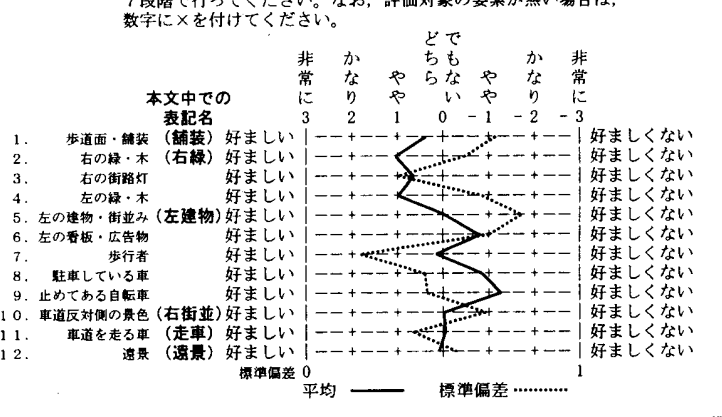

図 1 質問の概要および各評価結果のプロフィール 
実験対象の歩道景観は，長野県の県庁所在地である長野市から， 一般的な歩道景観の多種多様性を損なわないように選択されたも のである。実験では，長野駅周辺の商店街やオフィス街における步 道景観を 21 , 郊外住宅地の歩道景観を 8 , 合計 29 歩道景観を用い たのであるが，後に述べる理由により，21 歩道景観を分析・考察対 象としている。分析・考察対象の歩道景観を写真 1 に示す。写真は 葉書大（2L 版）に引き伸ばし，A5版のケント紙に貼付して被験者 に提示している。写真撮影の基準を表 1 に示す。実験は 1996 年 9 月 9 日から 11 月 16 日までの間に, 信州大学工学部社会開発工学科 建築コースの研究室内で行った。平均所要時間は 50.4 (分/被験者) である。また, 被験者の人数は, 建築系 17 名（内学生 16 名）, 非 建築系 10 名（内学生 5 名）の, 計 27 名である。

評価実験に用いた質問の概要および各評価結果のプロフィール を図 1 に示す。質問 1 は，歩道景観全体を対象とした，“好ましい 一好ましくない”という形容詞尺度を用いた 7 段階評定の評価実験 である。質問 2 は，構成要素の注目度を測るための指摘法実験であ る。質問 3 は, 12 構成要素を対象とした，“好ましい一好ましくな い”という形容詞尺度を用いた 7 段階評定の評価実験である。対象 とした 12 構成要素は, (1)歩道面・鋪装, (2)右の緑・木, (3)右の街 路灯, (4)左の緑・木, (5)左の建物・街並み, (6)左の看板・広告物, (7)歩行者，(8)駐車している車，(9)止めてある自転車，(10)車道反対側 の景色，(11)車道を走る車，(12遠景である。これらは，歩道景観にお いて重要と思われる構成要素であり，既往研究注 7)を参考に設定し ている。

12 構成要素のうち, 緑・木, 街路灯, 建物・街並み, 看板・広告 物については，左右にあるものを区別して評価させた。表 1 の写真 撮影基準(3に示すように，撮影は車道の左側の歩道において行った のであるが，この位置からは左側に敷地，右側に車道があることに なる。したがって，左の緑・木は主に私有地にあるもので，右の緑・ 木は主に公共のものである。街路灯については，歩車を分離する位 置にあるものだけを評価させた。また，建物・街並み，看板・広告 物について, 歩道の左側にあるものに対しては, 左の建物・街並み, 左の看板・広告物として個別に評価させているが，歩道の右側にあ るものについては，ほとんどの場合に車道の反対側にあるので，個
別に評価させることはせずに, 車道反対側の景色としてまとめて評 価させた。

遠景については，(1)から(11)までの構成要素が個別に判別できない 距離より遠方にある構成要素とした。具体的には, 実験に用いた写 真において歩行者が $3 \mathrm{~mm}$ (面積率算定のための最小単位) 以下とな る距離以遠の景観を遠景として扱っている。

しかし，すべての写真に 12 構成要素のすべてが含まれているわ けではない。実験では，質問 3 において，構成要素の有無を被験者 に判断させ, 判断が誤っている場合はそのことを教示して再評価さ せている。分析においては, 含まれている構成要素によって景観を 分類し，分類ごとに分析をする方法も考えられるのであるが，本研 究の目的は, 景観や構成要素の個別のあり方ではなく，景観認識の され方を考察することにあるので，できるだけ多くの景観に，最も 多く共通する構成要素を分析の対象とした。よって, 29 歩道景観の 12 構成要素を対象にして行った実験のうち, 最大の共通集合となる 21 歩道景観の 6 構成要素について分析を行った。省いた構成要素の 例として，歩行者については，景観への影響が大きいと考えられる のであるが，地方都市であるために普段から人通りが少なく，分析 では省いている。なお，図 1 に示すように，本文中では 6 構成要 素の名称を,「歩道面・舗装」を「舗装」,「右の緑・木」を「右緑」,

「左の建物・街並み」を「左建物」，「車道反対側の景色」を「右街 並」、「車道を走る車」を「走車」，と省略して表記する。

\section{4．歩道景観評価実験の結果と考察}

表 2 に実験結果を示す。この表では，各評価結果の值は全被験者 の平均值として算出されている注 10)。注目度の数値は, その構成要 素を指摘した被験者の人数である。なお，注目度として人数を用い たのは，注目度が構成要素の性質であると考えたことによるもので ある。すなわち，質問 2 において，言葉による回答の他に注目した 構成要素を写真上に印を付けて回答させる方法もとっており，被験 者の総指摘数には回答に対する労力等の影響が最小限となる工夫 をしているので, 総指摘数の多少は各構成要素が獲得した注目の指 標になっていると考えた。よって，各被験者の総指摘数による標準 化は行っていない。面積率の数值は, 写真全体を $42 \times 65$ のグリッ

\section{表 2 実駼結果}

\begin{tabular}{|c|c|c|c|c|c|c|c|c|c|c|c|c|c|c|c|c|c|c|c|}
\hline \multirow{2}{*}{ 写真番号 } & \multirow{2}{*}{$\begin{array}{l}\text { 全体の } \\
\text { 䚽価 }\end{array}$} & \multicolumn{6}{|c|}{ 構成要雩の評価 } & \multicolumn{6}{|c|}{ 棰成要素の注目度 } & \multicolumn{6}{|c|}{ 檴成要䡕の面積率 } \\
\hline & & 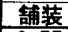 & 右緑 & 左建物 & 若街並 & 走車 & 遠景 & 舗装 & 右緑 & 左建 & 右街並 & 走車 & 遠景 & 磗装 & 右緑 & 左建物 & 五街並 & 走車 & 遠㟟 \\
\hline 1 & 0.56 & 0.77 & 1.54 & -0.54 & 0.54 & 0.15 & 0.58 & 12 & 19 & 7 & 3 & 0 & 1 & 23.88 & 4.94 & 38.17 & 13.03 & 0.00 & 0.71 \\
\hline & 1.32 & 0.38 & 1.38 & 1.46 & -0.42 & 0.08 & 1.38 & 18 & 13 & 9 & 3 & 0 & 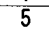 & 36.67 & 2.56 & 22.53 & 8.28 & 0.64 & 3.35 \\
\hline & 1.24 & 0.54 & 1.42 & 0.65 & -0.04 & 0.08 & -0.31 & & 15 & 4 & 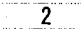 & 0 & 4 & 23. 19 & 16.12 & 13.53 & 17 & 1.14 & 1.14 \\
\hline & 0.56 & 0.27 & 1.12 & 0.19 & 0.23 & 0.08 & -0.54 & 4 & 10 & 17 & 2 & 0 & 3 & 25.57 & 10.33 & 37.18 & 10.35 & 1.34 & 1.23 \\
\hline & -0.96 & 0.77 & 1.15 & -1.12 & -0.77 & -0.19 & -0.54 & 6 & 13 & 1 & 0 & 0 & 2 & 32 & 25.75 & 18 & 4. & 1.43 & 3 \\
\hline 6 & -0.92 & 0.88 & 1.08 & -0.19 & -0.77 & -0.12 & -0.38 & 3 & 12 & 1 & 2 & 0 & 0 & 10 & 11.37 & & & 2.38 & \\
\hline 7 & -0.64 & 0.65 & 1.23 & -0.23 & -0.77 & -0.08 & -0.50 & 3 & 12 & 1 & 0 & 0 & 1 & 20.42 & 9.47 & & 13 & 1.06 & 55 \\
\hline & -0.96 & -0.08 & 0.23 & -1.00 & -0.58 & -0.04 & -0.42 & 6 & 6 & 13 & 3 & 0 & 0 & 22.34 & 1.94 & & & 0.18 & 3 \\
\hline$\overline{9}$ & -0.92 & 0.38 & 0.85 & -1.19 & -0.88 & -0.50 & -0.35 & 4 & 9 & 1 & 0 & 0 & 0 & 22.97 & 13.50 & 15 & & 2.66 & 0 \\
\hline 10 & -0.96 & -0.04 & -0.38 & -0.73 & -0.23 & 0.08 & 0.2 & 0 & 0 & 5 & 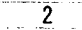 & 0 & 2 & 17.44 & 3.30 & 32 & & 0.62 & 3. 55 \\
\hline 11 & 0.08 & 0.38 & 0.46 & 0.00 & -0.50 & -0.12 & 0. & 10 & 11 & 11 & 0 & 0 & 2 & 16.74 & 13.46 & & & 1.41 & \\
\hline 12 & 0.20 & 0.35 & 0.08 & 0.04 & -0.50 & -0.27 & 0.1 & 3 & 0 & 2 & 3 & 1 & 2 & 19.03 & 0.22 & & & 2.22 & 5 \\
\hline 13 & -0.04 & 03 & 0.35 & 0.12 & -0.31 & -0.12 & -0. & 1 & 5 & 9 & 2 & 0 & 0 & 17.07 & 5.02 & & & 0.02 & 6. \\
\hline 14 & -0.28 & 0.96 & 0.65 & -0.46 & -0.50 & -0.54 & -0.65 & 7 & 6 & 9 & 0 & 0 & c & 26.56 & 5.18 & & & & \\
\hline 15 & 0.32 & 0.92 & 1.38 & -0.65 & -0.23 & -0.62 & -0.08 & 6 & 11 & 9 & 0 & 0 & 4 & 24.80 & 22. 27 & 19 & & 0.98 & 7.12 \\
\hline 16 & 1.92 & 0.7 & 1.81 & 0.58 & 1.46 & 0.50 & 1.27 & 1 & 21 & 1 & 9 & 0 & 0 & 23.45 & 9.96 & 8.77 & 17.70 & 0.48 & 0.40 \\
\hline 17 & 0.40 & 0.46 & 1.65 & -0.96 & 0.73 & 0.08 & -0.42 & 4 & 20 & 3 & $i$ & 0 & & 27.40 & 18.33 & & & 0. & 1.10 \\
\hline 18 & 1.60 & 1.54 & 1.62 & 1.88 & 0.92 & 0.19 & 0.27 & 10 & 15 & 19 & 1 & 0 & 0 & 21.14 & 20.02 & & & 0.16 & 00 \\
\hline 19 & 1.12 & 0.23 & 1.62 & 0.73 & 0.96 & 0.19 & 0.58 & $?$ & 19 & 3 & 4 & 0 & 1 & 25.77 & 17.09 & 10.57 & & 0.13 & 0.00 \\
\hline 20 & 0.08 & 0.46 & 0.50 & 0.19 & -0.50 & -1.42 & -0.31 & 6 & 5 & 0 & 2 & 10 & 0 & 23.63 & 15.26 & & & 4.62 & 0.44 \\
\hline 21 & -0.84 & 0.00 & 0.96 & -1.08 & -0.54 & -0.19 & -0.50 & 2 & 4 & 6 & 4 & 0 & 0 & 22.51 & 13.64 & & & 1.15 & 1.10 \\
\hline 平 & 0.14 & 0.52 & 0.99 & -0.11 & -0.13 & -0.13 & -0.01 & 5.81 & 11.05 & 6.62 & 2.33 & 0.52 & 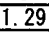 & 22.82 & 11.42 & 27.58 & 8. & 1.25 & 1.39 \\
\hline
\end{tabular}


表 3 相関係数行列

\begin{tabular}{|c|c|c|c|c|c|c|c|c|c|c|c|c|c|c|c|c|c|c|c|}
\hline & $\begin{array}{l}\text { 全体 } \\
\text { 鲜俩 }\end{array}$ & 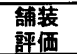 & $\begin{array}{l}\text { 右緝 } \\
\text { 鲜值 }\end{array}$ & $\begin{array}{l}\text { 左建物 } \\
\text { 評価 }\end{array}$ & 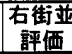 & \begin{tabular}{|l} 
走車 \\
評価
\end{tabular} & 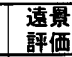 & 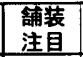 & $\begin{array}{l}\text { 右緑 } \\
\text { 注目 }\end{array}$ & \begin{tabular}{|c|} 
龙建物 \\
注目
\end{tabular} & 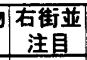 & $\begin{array}{l}\text { 走車 } \\
\text { 注目 }\end{array}$ & $\begin{array}{l}\text { 逵暴 } \\
\text { 注目 }\end{array}$ & 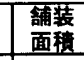 & $\begin{array}{l}\text { 右粶 } \\
\text { 面積 }\end{array}$ & $\begin{array}{l}\text { 灰建物 } \\
\text { 面程 } \\
\end{array}$ & $\begin{array}{l}\text { 石街並 } \\
\text { 面矰 }\end{array}$ & 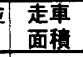 & 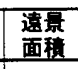 \\
\hline 全体評保 & $\frac{1.00}{1.00}$ & & & & & & & & & & & & & & & & & & \\
\hline 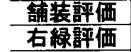 & $\begin{array}{l}0.36 \\
0.61\end{array}$ & $\begin{array}{l}1.00 \\
0.53\end{array}$ & 1.00 & & & & & & & & & & & & & & & & \\
\hline & 0.80 & 0.37 & 0.34 & 1.00 & & & & & & & & & & & & & & & \\
\hline & 0. & 0.25 & 0.59 & 0.46 & 1.00 & & & & & & & & & & & & & & \\
\hline & $\begin{array}{l}0.40 \\
0.66\end{array}$ & $\frac{-0.01}{0.05}$ & $\begin{array}{l}0.38 \\
0.26\end{array}$ & $\begin{array}{l}0.29 \\
0.57\end{array}$ & $\frac{0.57}{0.51}$ & $\frac{1.00}{0.45}$ & 1.0 & & & & & & & & & & & & \\
\hline 薄策 & 0.32 & 0.24 & 0.16 & 0.38 & -0.05 & 0.04 & 0. & 1.00 & & & & & & & & & & & \\
\hline & 0.62 & 0.40 & $\begin{array}{r}0.90 \\
-0.08\end{array}$ & $\begin{array}{l}0.31 \\
0.37\end{array}$ & \begin{tabular}{|l|l|}
0.69 \\
\end{tabular} & $\frac{0.52}{0.00}$ & 0.3 & $\begin{array}{l}0.16 \\
0.39\end{array}$ & $\begin{array}{r}1.00 \\
-0.04\end{array}$ & 1.0 & & & & & & & & & \\
\hline & 0. & $\frac{.10}{-0.17}$ & 0.26 & 0.25 & \begin{tabular}{|l}
0.4 \\
\end{tabular} & & & -0.30 & 0.24 & -0.30 & 1.00 & & & & & & & & \\
\hline & & -0.04 & -0.22 & 0.09 & -0.14 & -0.75 & & & -0.26 & 0.04 & -0.1 & $\begin{array}{l}00 \\
18\end{array}$ & (0) & & & & & & \\
\hline & 0. & $\frac{-0.07}{0.01}$ & 0.10 & 0.27 & $\frac{-0.11}{0.23}$ & $\frac{0.10}{0.04}$ & $\frac{0.29}{0.31}$ & $\frac{0.53}{0.48}$ & $\frac{0.08}{0.39}$ & $\frac{0.11}{0.12}$ & $\frac{-0.16}{0.09}$ & $\frac{-0.18}{0.02}$ & $\frac{1.00}{0.35}$ & & & & & & \\
\hline 石构 & & \begin{tabular}{|l|}
0.04 \\
0.42
\end{tabular} & 0.50 & $\frac{0.30}{-0.03}$ & $\frac{0.25}{0.17}$ & -0. & -0.23 & -0.09 & 0.43 & -0.06 & -0.32 & 0.09 & 0.03 & -0.07 & 1.00 & & & & \\
\hline 在建 & -0.20 & -0.10 & -0.48 & -0.05 & -0.16 & & -0.2 & 0. & -0.3 & 0.64 & -0.29 & 0.24 & -0.19 & -0.25 & -0. & & & & \\
\hline 右佳 & 0.17 & -0.13 & 0.15 & 0.12 & 0.32 & 0.40 & 0. & -0.18 & 0.25 & -0.13 & 0. & 0.00 & -0.32 & & -0.48 & $\begin{array}{l}-0.05 \\
0.05\end{array}$ & 1.00 & & \\
\hline 素 & -0. & 0.06 & -0.30 & -0.19 & -0.51 & -0.83 & -0.40 & -0.10 & -0.39 & $\begin{array}{r}-0.19 \\
0.17\end{array}$ & $\begin{array}{l}-0.30 \\
-0.22\end{array}$ & 0.70 & $\frac{-0.15}{0.43}$ & -0.02 & $\frac{.09}{06}$ & $\begin{array}{l}0.05 \\
0.05\end{array}$ & $\frac{-0.21}{-0.44}$ & 1. & \\
\hline & & -0.08 & -0.17 & -0.03 & & & & 15 & & 17 & 22 & & & & & $0 b$ & 44 & & \\
\hline
\end{tabular}

ド（1 グリッドは, 約 $3 \mathrm{~mm}$ 四方の正方形) に分割して計測された, 各構成要素注 11) が占めるグリッド数の写真全体の全グリッド数に 対する百分率である。

表 2 から算出された, 歩道景観全体の評価・各構成要素の評価・ 注目度・面積率による, それぞれ相互の全相関係数の行列を表 3 に 示す。この表から，歩道景観全体の評価と強い相関があるもの注 12) として, 左建物の評価・右街並の評価があげられる。また，相関が あるものとして, 右緑の評価・遠景の評価・右緑の注目度があげら れる。

次に，各構成要素ごとに，評価・注目度・面積率がどのような関 倸にあるかを考察する。評価・注目度・面積率それぞれの各構成要 素における関倸のあり方は次のようにまとめられる。

(1) 評価・注目度・面積率すべてが相互に相関している。

(2) 評価・注目度は相関しているが面積率だけが相関していない。

(3) 評価・面積率は相関しているが注目度だけが相関していない。

(4) 注目度・面積率は相関しているが評価だけが相関していない。

(5) 評価・注目度・面積率のうちどれも相関していない。

各構成要素ごとに，評価・注目度・面積率のうちの 2 つの関係を 詳細に考察するために，偏相関係数を算出した（表 4)。これを見 ると，(2)として右緑が，(3)として走車（ただし評価だけが他と逆の 相関となっている。）が，(4)として左建物・右街並が，(5)として舗 装・遠景があげられる。なお，(1)あたる構成要素はない。

さらに，各構成要素ごとに，歩道景観全体の評価と構成要素の評 価・注目度・面積率との関係を考察していく。表 3 から, 歩道景観 全体の評価と各構成要素ごとの評価・注目度・面積率それぞれとの 相関係数を抜粋したものを表 5 に示す。この表では，先に考察され た各構成要素ごとの評価・注目度・面積率それぞれの関係で, 相関 していると考察されたものを網掛けによって示している。各構成要 素ごとに, 各関倸を整理していく。

(1) 舗装 : 全体の評価・構成要素の評価・構成要素の注目度・構成 要素の面積率のうちの，すべての関倸に相関がない。ただし， 表 2 から, 注目度・面積率の平均值は比較的大きく, 注目はさ れていると考えられる。

(2) 右緑 : 全体の評価・構成要素の評価・構成要素の注目度が相互 に相関している。特に, 構成要素の評価と構成要素の注目度と の相関は強い。注目度の平均值も大きく，よく注目されている。
表 4 構成要素ごとの偏相関係数

\begin{tabular}{|c|c|c|c|c|c|}
\hline 朝装 & 評価 & 注目度 & 右街亚 & 鲆傮 & 注目度 \\
\hline$\frac{\text { 注自度 }}{\text { 面梖率 }}$ & $\begin{array}{r}0.254 \\
-0.094\end{array}$ & 0.487 & $\begin{array}{l}\text { 注貝度 } \\
\text { 面椣卒 }\end{array}$ & $\begin{array}{r}0.267 \\
-0.049 \\
\end{array}$ & $0 . \overline{831}$ \\
\hline 右龻 & 評価 & 注目度 & 莡軍 & 鲆価 & 注目度 \\
\hline $\begin{array}{l}\text { 注目度 } \\
\text { 面糟 }\end{array}$ & $\begin{array}{l}0.877 \\
0.354\end{array}$ & -0.117 & 注目度 & $\begin{array}{l}-0.440 \\
-0.641\end{array}$ & 0.198 \\
\hline 左建物 & 鲆傮 & 汪目度 & 䈱意 & 評洒 & 注目度 \\
\hline 注目度 & 0.523 & - & 注目度 & 0.274 & - \\
\hline 面積率 & -0.400 & 0.709 & 面㮴率 & -0.028 & 0.425 \\
\hline
\end{tabular}

表 5 .各構成要素ごとの全体の評価との相関係数の抜粋

\begin{tabular}{|c|c|c|c|c|}
\hline & \multicolumn{4}{|c|}{ 全体の評価と } \\
\hline & $\begin{array}{c}\text { 構成要繋の } \\
\text { 評価との } \\
\text { 相関係数 }\end{array}$ & $\begin{array}{c}\text { 棈成要妻の } \\
\text { 注目度との } \\
\text { 相関係数 }\end{array}$ & 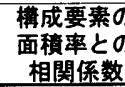 & \\
\hline 部装 & 0.355 & 0.319 & 0.450 & - \\
\hline 右緑 & $0.615 \Delta$ & 0.616 & 0.109 & - \\
\hline 左建物 & 0.802 & 0.29 & 0.201 & - \\
\hline 右街並 & 0.786 & 0.324 & 0.173 & -2 \\
\hline 走車 & 0.400 & -0.013 & -0.327 & - \\
\hline 遠亮 & 0.655 & 0.294 & 0.031 & $=$ \\
\hline
\end{tabular}

面積率の平均值は大きくない。

（3）左建物：全体の評価・構成要素の評価が相互に強く相関してい る。注目度・面積率については，相互は相関しているが，これ らと全体の評価との関係には相関がない。構成要素の評価・注 目度は正の相関, 構成要素の評価・面積率は負の相関であり, 複雑な相関関係が見られる。注目度の平均値も比較的大きい。 面積率の平均値は大きい。

（4）右街並: 左建物同様, 全体の評価・構成要素の評価が相互に強 く相関している。注目度・面積率については，相互は強く相関 しているが，これらと全体の評価との関係には相関がない。注 目度・面積率の平均值は小さく，あまり注目されていない。

（5）走車：構成要素の評価・構成要素の面積率が相互に相関してい る。負の相関である。しかし，これらと全体の評価との関係に は相関がない。注目度・面積率の平均值は小さく，ほとんど注 目されていない。

（6）遠景：全体の評価・構成要素の評価が相互に相関している。他 の関係には相関がない。注目度・面積率の平均値は小さく, ほ とんど注目されていない。

\section{5. 全相関関係の視覚化}

表 3 に示される全相関関係を視覚化するために, MDS（多次元尺 
度構成法) 注 13) を用いて図を作成した。MDSへの入力データは, $\mathrm{r}=\cos$ $\theta \quad\left(\mathrm{r}:\right.$ 相関倸数, $\left.0^{\circ}<=\theta<=180^{\circ}\right)$ という関係から算出されたう ジアンとしての $\theta$ を值に用いて作成した距離行列である。入力距離 行列と, 1 9 次元での計算における各出力距離行列との相関係数の 変化を図 2 に示す。本研究では，全相関関係を視覚化するために MDS を用いるので, 3 次元の計算を用いることにする。計算結果の 布置図を図 3 (第 I 次元 $\times$ 第 II 次元）と図 4 （第 I 次元 $\times$ 第 III 次元） に示す。第 I 次元は全体の評価との相関性（左端は負の相関），第 III 次元は遠景と右街並の区別, 第吕次元は右緑の面積率との関連性, と解釈される。この図に布置されている各点の位置は, 表 3 に示さ れた全相関関係をほぼ正確に表していることが確認できる。

これまでの考察から，実験結果として，歩道景観構成要素は以下 のようにまとめられる。

1）全体の評価との関係による構成要素の分類

・全体の評価と相関がある：右緑・左建物・右街並・遠景

・全体の評価と相関がない: 舖装・走車

2）構成要素の評価・注目度・面積率の相互相関関係による構成要 素の分類

・評価・注目度が相互に相関 : 右緑

・注目度・面積率が相互に相関 : 左建物・右街並

・評価・面積率が相互に相関：走車

・相関なし：舗装・遠景

\section{6. 実験結果に見られる景観認識のあり方の考察}

実験により，右緑・左建物・右街並・遠景は全体の評価と相関が ある構成要素, 舗装・走車は全体の評価と相関がない構成要素であ ることが整理されたのであるが，この結果に基づいて景観認識のあ り方を考察していく。

まず，全体の評価と構成要素の評価とに強い相関があり，注目 度・面積率が相互に相関している構成要素である左建物・右街並に ついて考察する。これらの構成要素は，注目度・面積率が相互に相

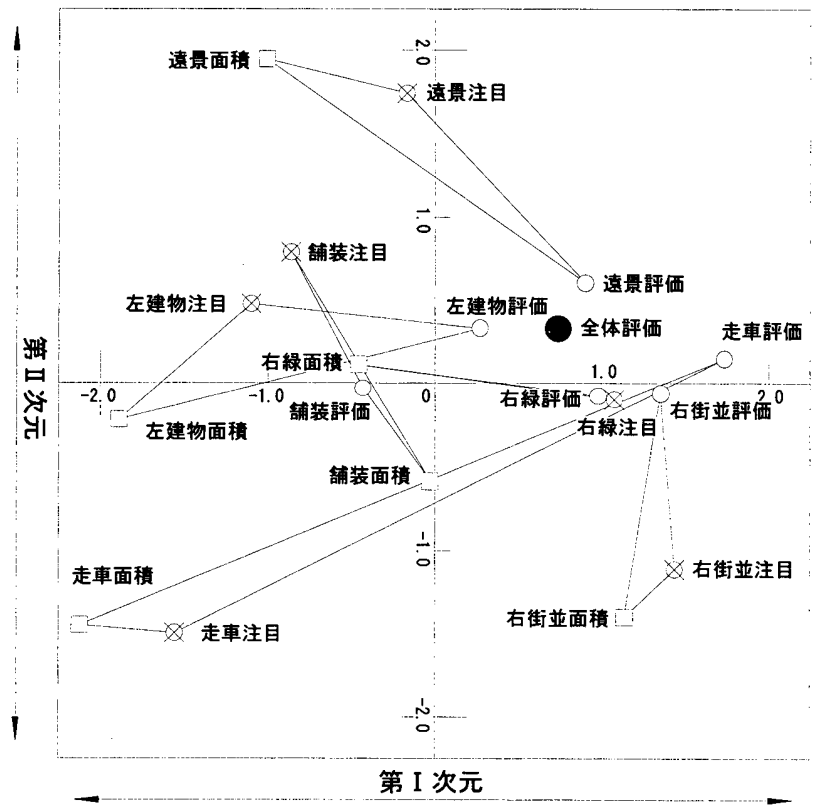

図 3 MDS による布置図（第 I 次元 $\times$ 第 II 次元）
関しているのであるが，このことから，これらの構成要素は，面積 率が大きければ注目され，小さければ注目されないものであること が示される。そして, 注目度の程度とは別に評価が行われ，同程度 に注目した場合でも“好ましい”と評価される場合も“好ましくな い”と評価される場合もあり，そのため，これらの構成要素では， 注目度や面積率と全体の評価や構成要素の評価との関係には，相関 がないという結果になっていると考えられる。以上から，左建物・ 右街並に対しては，注目度・面積率における景観認識と評価のため の景観認識とは異なっていること, 構成要素評価のための景観認識 と全体評価のための景観認識とは強く関連していること，が考えら れる。

次に, 全体の評価と構成要素の評価とに相関があり, 構成要素の 評価・注目度が相互に強く相関している構成要素である右緑につい て考察する。この構成要素は, 構成要素の評価・注目度が相互に強 く相関しているのであるが，このことから，この構成要素は，注目 されればされるほど “好ましい”と評価されるものであることが示 される。また，面積率とは相関がないことから，評価は面積によっ て行われていないことが示される。以上から，右緑に対しては，構 成要素の注目度・評価は意味に基づいて景観認識が行われているこ と, 構成要素評価のための景観認識と全体評価のための景観認識と は関連していること，が考えられる。

遠景については，全体の評価・構成要素の評価が相互に相関して いる以外には相関が見られない。また，ほとんど注目されていない。

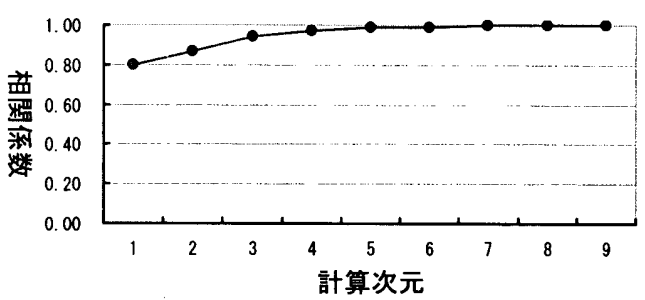

図 2 入力距離行列と出力距離行列との相関係数

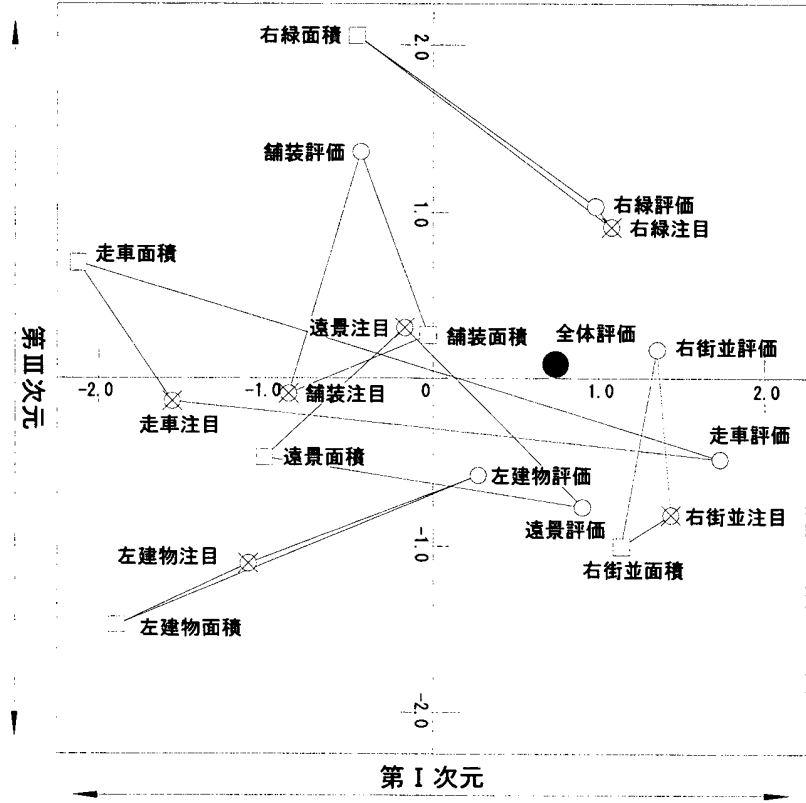

図 4 MDS による布置図（第 I 次元 $\times$ 第吕次元） 
本研究では，遠景を構成要素が個別に判別できない距離より遠方に ある構成要素としたのであるが，被験者にはこの定義による遠景の 認識が困難であったため, 右緑・左建物・右街並の評価が遠景の評 価に影響してしまったことが考えられる。遠景だけを隠して評価し た場合と全体景観を評価した場合との比較など，教示にはよらない 実験の工夫が必要であろう。

舗装については，全体の評価との関係が見られなかったのである が，注目はされていると考えられることから，個別の景観ごとに， 景観認識の特徵が大きく異なっていると考えられる。すなわち，面 積はどの景観でもほぼ一定であるのに対し，注目される場合・され ない場合があり，注目される場合でも，“好ましい”場合・“好まし くない”場合等があることが考えられる。また，鋪装の評価が“好 ましい”場合でも，全体の評価は“好ましい”場合・“好ましくな い”場合等があることが考えられる。

最後に，走車については，全体の評価との関倸は見られず，注目 もされていない。しかし，構成要素の評価・面積率が相互に相関し ていることから, 構成要素の単位では面積率が大きければ “好まし くない”という評価がされていると考えられ，構成要素の単位では 物理量に基づく景観認識がされていると考えられる。このような構 成要素は, 左建物・右街並や右緑とは異なる対象としてあり，人々 には構成要素の単位で “好ましくない”と評価されるものであると 考えられる。しかし，車道を走る車が網膜に何ら刺激を与えていな いとは考えにくく，構成要素の単位では評価がなされていることを 考慮すると，全体評価との関係が見られないこと，注目されていな いことは，意識によって景観から切り離された単独の評価が行われ た結果であると考えられる。このように認識される構成要素に対し ては，写真を見て評価させるなどの実験の他に，記憶やイメージな どにおける評価構造そのものの検討が必要になるであろう。

\section{7.まとめ}

景観認識のされ方を，歩道から見た景観における「全体評価」と 「構成要素の評価・注目度・面積率」との関係から捉えるために, (1)歩道景観全体の評価，(2)各歩道景観構成要素の評価，(3)各歩道景 観構成要素の注目度, (4)各歩道景観構成要素の写真に占める面積率, といった 4 つの内容相互の関係を探った。

（1）実験の結果，歩道景観構成要素が次のように分類された。

1）全体の評価との関係による構成要素の分類

・全体の評価と相関がある：右緑・左建物・右街並・遠景

・全体の評価と相関がない: 舗装・走車

2）構成要素の評価・注目度・面積率の相互相関関係による構成 要素の分類

・評価・注目度が相互に相関 : 右緑

・注目度・面積率が相互に相関 : 左建物・右街並

・評価・面積率が相互に相関：走車

・相関なし：舖装・遠景

（2）左建物・右街並に対しては，注目度・面積率における景観認識 と評価のための景観認識とは異なっていること, 構成要素の評 価のための景観認識と全体評価のための景観認識とは強く関 連していること,が考察された。
（3）右緑に対しては, 構成要素の注目度・評価は意味に基づいて景 観認識が行われていること, 構成要素の評価のための景観認識 と全体評価のための景観認識とは関連していること, が考察さ れた。

（4）走車に対しては，意識によって景観から独立した評価がなされ るような認識が行われていること，が考察された。

\section{8. 今後の課題}

(1) 今回対象にした構成要素は, 最終的に 6 構成要素のみが分析・ 考察対象となったのであるが，さらに構成要素を景観認識のあ り方を考察していく必要がある。

(2) 本研究では, 歩道景観全体の評価・構成要素の評価・注目度・ 面積率といった 4 つ值を対象にして分析・考察しているが， この他の測り得る値についても検討し，それらの值にどのよう に景観認識のあり方が表れるのか考察していく必要がある。特 に，景観における色彩については，注目度・面積率における認 識と評価のための認識とが異なっているのか，あるいは，意味 が認識されているのか等，様々な場合が考えられることから， 詳細な考察が必要である。

本研究の実験は, 修論生であった辻佳博氏の協力を得たこと, 平成 $7 \cdot 8$ 年度文 部省科学研究費補助金の補助を受けたこと(基盤研究 (C) (2)・研究代表者:山口 満·課題番号 07805055)を,ここに記して感謝の意を表します。

注

1）参考文献 1) 2) 3)

2）参考文献 4) 5) 6)

3) 参考文献 7) 8)

4）参考文献 9１0１11)

5）参考文献 12）13）

6) 参考文献 14)

7) 参考文献 15)

8）ここでは視覚について説明しているが, 知覚可能な刺激であれば, どのような感 覚についてもこのような説明が可能である。そして，実際には複数の感覚による 複合的な刺激によって認識が行われていると考えられる。

9）実験は，参考文献 18)に基づいて，新たに計画・実行されたものである。

10) 分析・考察では, 多くの人に共通している景観の認識を仮定し, 結果の安定性 を高めるために平均値を用いている。

11）面積率は, 舖装·右緑·街灯·左緑·左建物・看板・歩行者·駐車·駐輪·右街 並・走車・遠景·その他·空といった 14 構成要素ごとに計测されており, 14 構成 要素の面積率の合計が 100 となる。

12) $\mathrm{r}=\cos \theta\left(\mathrm{r}:\right.$ 相関係数, $0^{\circ}\left\langle=\theta<=180^{\circ}\right)$ という関係において, $\theta<=45^{\circ}$ は, $r\rangle=1 / \sqrt{2}$ となる。本研究では, $0^{\circ}\left\langle=\theta<=45^{\circ}\right.$ を強い相関がある」, $45^{\circ}<\theta$ $\left\langle=60^{\circ}\right.$ を相関がある」, $60^{\circ}<\theta<120^{\circ}$ を「相関がない, $120^{\circ}<=\theta<135^{\circ}$ を 「逆の相関がある」, $135^{\circ}<=\theta<=180^{\circ}$ を強い逆の相関がある」, と表記してい る。

13）東京大学大型計算機センター(旧称)のSAS を使用した。なお, MDS の詳細に ついては, 参考文献 3)を参照。

\section{参考文献}

1) 奥 俊信: 瞬間視実験に基つく街路景観構成要素の分析一街路景観の視覚特 性ならびに心理効果に関する実験的研究 第1報, 日本建築学会論文報告集, No.321, pp.117 124, 1982.11

2）奥 俊信: 街路景観構成要素の景観評価への影響について一街路景観の視賞 特性ならびに心理効果に関する実験的研究 第2 報, 日本建築学会計画系論 文報告集, No.351, pp.27 37, 1985.5

3）奥 俊信: 街路景観構成要素と心理的効果の関保一主としてまとまりの良さにつ いてー街路景観の視覚特性ならびに心理効果に関する実験的研究 第3 報, 日本建築学会計画系論文報告集, No.389, pp.108 115, 1988.7 
4）船越 徹, 積田 洋: 街路空間における空間意識の分析 (心理量分析) 一街路 空間の研究 (その 1$)$ - 日本建築学会論文報告集, No.327, pp.100 107, 1983.5

5）船越 徹, 積田 洋: 街路空間における空間構成要素の分析 (物理量分析) 街路空間の研究 (その2) - , 日本建築学会計画系論文報告集, No.364, pp.102 111, 1986.6

6) 船越 徹,積田 洋:街路空間における空間意識と空間構成要素との相関関倸 の分析 (相関分析) 一街路空間の研究 (その3) 一, 日本建築学会計画系論文 報告集, No.378, pp.49 57, 1987.8

7) 松本直司, 寺西敦敏, 仙田 満: 街路景観の乱雑·整然性要因に関する研究一 中心市街地における乱雑·整然性に関する研究 その 1 -, 日本建築学会計画 系論文報告集, No.429, pp.73 82, 1991.11

8）松本直司，高井智代: 個人差をふまえた街路景観の乱雑・整然性および魅力 度の関連一中心市街地における乱雑·整然性に関する研究 その $2-$, 日本建 筑学会計画系論文報告集, No.440, pp.89〜98, 1992.10

9) 槙 究, 乾 正雄, 中村芳樹: 街路景観の評価構造の安定性, 日本建築学会計 画系論文集, No.458, pp.27 33, 1994.4

10)植究, 乾 正雄, 中村芳樹: 評価項目が街路景観評価に及ぼす影響, 日本建 築学会計画系論文集, No.468, pp.27 36, 1995.2

11)槙 究, 乾 正雄, 中村芳樹: 街路景観評価の個人差について, 日本建築学会
計画系論文集, No.483, pp.55 62, 1996.5

12)高木清江, 瀬尾文彰, 松本直司: 環境の文化特性に関する考察一環境の<詩 性>に関する研究 その1-, 日本建築学会計画系論文集, No.502, pp.117〜 $123,1997.12$

13)高木清江, 瀬尾文彰, 松本直司: <詩性>の研究方法に関する考察－環境の <詩性>に関する研究 その2-, 日本建築学会計画系論文集, No.518, pp. $153 \sim 160,1999.4$

14)辻川ひとみ, 北浦かほる, 斎木陽子:都市における空間構成要素の位置つけ一 ストリート・ファニチュアの定義と分類一, 日本建築学会計画系論文集, No.520, pp.233 238, 1999.6

15)山口 渵, 志水英樹, 鈴木信弘:駅前広場における物理的要素の好ましさと全 体景観の評価との関連構造に関する研究, 日本建築学会計画系論文集, No.467, pp.89 96, 1995.1

16)志水英樹, 鈴木信弘, 山口 満:駅前広場における景観の多様性と好ましさに 関する研究, 日本建築学会計画系論文報告集, No.445, pp.63 71, 1993.3

17)志水英樹, 鈴木信弘, 山口 満: 駅舎および周辺街並の知覚構造に関する研 究, 日本建築学会計画系論文報告集, No.433, pp.41 51, 1992.3

18)山口 満, 辻 佳博:歩道とその構成要素の評価に関する研究, 日本建築学会 北陸支部研究報告集, 第 38 号, pp.341 344, 1995.8 